\title{
EFFICIENT POSTAL SERVICE AND RESPECTFUL WITH THE ENVIRONMENT
}

\author{
José Antonio Vera López \\ Doctoral Student, University of Córdoba, Spain \\ Ana Belén Pabón Dueñas \\ Doctoral Student, University of Córdoba, Spain \\ Roberto José Liñán Ruiz \\ Doctorate Student, University of Córdoba, Spain \\ Salvador Merino Córdoba \\ Doctor, University of Málaga, Spain
}

\begin{abstract}
The postal service is suffering an adaptation to the new markets opened by the users. The traditional post, letters and postcards, is being used less and is substituted by mail and packaging. To adequate to this new market it's important for the postal sector companies.

In Spain, the operator of the Universal Postal Service has taken example from other companies of the sector, national and international, implanting electrical bicycle mail and packaging service in the centre of big cities. This is due to the fact that there are more the cities that are forbidding vehicle access to it's historical centres and the volume of packaging to deliver is greater.
\end{abstract}

But, is it viable to deliver using hybrid and electrical vehicles in cities? This study intends to improve the distribution in cities with the implantation of these vehicles. It takes into account the characteristics of populations between 50.000 and 100.000 inhabitants, in which it will be analysed the advantages and inconvenience, doing special emphasis in the economic cost, conducting studies of the costs of implantation and amortization time.

\section{THE POSTAL SECTOR IN SPAIN.}

The postal sector is suffering a profound transformation in the last decades, as a consequence of new habits and consumer requirements due to the rapid development of information and communications technology.

\subsection{Liberalization of postal sector.}

The European Union has stimulated the process of adaptation or the sector to the new economic context created by this transformation, promoting the opening up to competition trough various directives that have led the demand for a full opening of postal markets of the EU from 1 January 2011 to allow the apparition or a real market. 
The postal market in Spain has gone a long process until reaching the free competitive market. It all started with the elaboration in the EU the Green Paper on the development of the single market of postal services in 1999 and was inching forward in Spain with the transposition of fundamentally three directives:

- Directive 97/67/EC OF THE EUROPEAN PARLIAMENT AND OF THE COUNCIL of 15 December 1997 on common rules for the development of the internal market of Community postal services and the improvement of quality of service. Adopted in Spain by Law 24/1998 of 13 July, the Universal Postal Service and Liberalization of Postal Services.

- Directive 2002/39/EC OF THE EUROPEAN PARLIAMENT AND THE COUNCIL of 10 June 2001 amending Directive 89/67/EC with regard to the further opening to competition of Community postal services.

- Directive 2008/6/EC OF THE EUROPEAN PARLIAMENT AND OF THE COUNCIL of 20 February 2008 amending Directive 97/67/EC with regard to the full accomplishment of the internal market of Community postal services.

In Spain, the transposition of that directive was made by Law 43/2010, of 30 December, the universal postal service, the rights of de users and the postal market, which entered into force on 1 January 2011. This Postal Law eliminated the reserved area an opened to competition all postal services, which ended the part of the postal market reserved for Correos, although this Company was designated for 15 years as operator responsible for providing the universal postal service public service obligations, taking into account that manages the largest postal network covering the whole country.

\subsection{Postal market in Spain.}

The postal market consists of two segments:

- Traditional postal sector. Which basically includes the provision of delivery services and postal letters lightweight packages under standardized conditions, as well as sending periodicals, books, catalogues and direct mail.

- Industrial packaging activities, commercial parcel and courier. Postal services that are of higher value added, and now account for almost $80 \%$ of the turnover of the postal market in Spain.

Part of traditional postal services are provided with public service obligations by a designated operator. The universal postal service is the provision of basic postal services (sending letters and parcel up to a certain weight) with quality requirements: mailing and delivery throughout the country, with a certain frequency, affordable and usually uniform throughout the territory. The provision of this service also often requires the existence of certain infrastructure such as offices open to the public. Public postal sector operators who have been traditionally been responsible for providing this service, reserving the monopoly 
of the traditional postal service (reserve area) to cover the cost of the universal postal service.

The development of communications technologies and changes in consumer needs have caused the appearance of a process of substitution of traditional postal services by other media. In addition to facing competition from more specialized services of courier companies and parcel, traditional postal mail can be replaced by: telecommunications (email, instant messaging, internet, fax and telephone) and hybrid mail.

Substitutability sending letters and documents by electronic communications is high and appears to be accelerating with the current economic crisis, especially in business where postal deliveries are often part of the cost reduction programs.

The development of electronic communications also affects the characteristics of postal services that consumers demand. The immediacy of electronic communications incentives in particular the replacement of express postal for electronics communications. Consumer are willing, whenever possible, to prefer the immediacy that allows telematics communication, which requires an adaptation of the quality of services offered by postal companies.

\subsection{Demand of the postal service.}

Is possible to distinguish five large groups of plaintiffs for postal services attending to their needs:

- Homes, which comprises for individual complainants who use postal service for their personal communications with other individuals, businesses and public administrations.

- SMEs, which perform and receive deliveries as support for their activity but do not generate large volumes of mail.

- Major emitters, generally large companies that generate a large volume of shipments.

- Public administrations, a special case of high emitter using the postal service for their official communications with citizens.

- Companies for which the postal service is an essential element in your business, such as advertising and marketing, distance selling, publishing, etc.

The grater part of the shipments have as origin or destination organizations (business and public administrations), the residual traffic between individuals. These organizations are involved in approximately $90 \%$ or deliveries and the main flows are the organizations to homes.

The Spanish demand for traditional postal services is lower than that of surrounding countries, partly as a consequences of the reduced presence of direct advertising in Spain, attributed by industry sources to the difficulties that the legislation on data protection generates to develop an appropriate database, required for direct mail campaigns are 
efficient.

The spatial distribution of plaintiff's postal service has effects on the cost structure of postal operators. The existence of a low population density and the presence of a great number of areas with complicated orography and insular territories condition network investments collection and delivery of national scope. The effects on the costs of the lowest population density in Spain compared to other European countries are partly offset by the higher percentage of urban population.

\subsection{Characteristics of the offer in postal sector.}

The provision of postal services includes a series of activities of collecting, preparing and sorting, transport and final distribution. The set of productive resources required to perform the various activities is called postal network. Activities in the destination of consignments activities are commonly called downstream. The rest of previous activities are called upstream.

The stages of final distribution and classifications are those that have greater weight in the final cost, although there are some differences between the cost structure of letters and packages.

In the post productive process there are significant economies of scale combined with economies of scope and density, whose magnitude is different according to the various activities or links in the value chain (sorting, collection, distribution, etc.) and depending on the characteristics sending (letters, parcels).

These economies are associated with de density of distribution points and the number or articles per delivery point. As the distribution points are increased transportation costs increase, up to a point where the density of distribution points is such that the paths are no modified and each point does not generate additional distributions costs. Once you go to a delivery point, the cost of delivering a greater number of articles is very small. Only if the delivery volume is very large, the capacity of transportation can be overcome, exhausting economies of scale.

The magnitude of economies of scale in the distribution depend on a number of elements between which the emphasize the following:

- Product type: the delivery of letters, occupying a smaller volume, it is possible to obtain greater economies of scale that in the packets.

- Density of homes in the area of distribution: the higher density, greater economies of scale.

- Size distribution area: economies of scale increase as the size is reduced.

- Delivery frequency: the higher it is, the less volume accumulates of articles for 
distribution, and so lower the economies of scale.

- Number or articles delivered per delivery points: mass mailings allow to reach greater economies of scale.

In short, when deliveries individually, must be delivered faster and their distribution can not be planned, some circumstances that usually appear as service postal universal, obligations it is not likely that the demand is high enough to allow the use of economies of scale in the collection and, above all, in the distribution. This makes the return on investment in postal delivery networks, especially in areas with low population density and difficult terrain.

It is usual to distinguish two market areas in response to the unit costs of providing the traditional postal service:

- High cost areas. This is usually rural areas, sparsely populated and low business density, where the reduced volume of deliveries increases unit costs. Un these areas it is unlikely that there are several competing networks simultaneously. In addition, compliance with the public service obligations requires the existence of a portal network managed by the operator designated to provide the service postal universal even in environments where it is not profitable.

- Low cost areas. This is usually urban areas with high population density and a great number of companies. Collection activities and, to a greater extent, have a reduced final distribution by the existence of significant economies of scale and density, which facilitate the profitability or the postal network unit cost. In these areas, demand may be high enough to attract new operators. The volume of demand may allow a doubling of efficient networks.

\section{DISTRIBUTION NETWORKS.}

Transport networks arise from the need to connect and transport consumer goods from point of production to the market. In the distribution stage, the merchandise can be transported with a variety of modes of transport (rail, air, sea, river or road) and can make several stops in stores or nodes modal shift until you reach your destination final.

The configuration of the transport network affects the costs of production of good as well as planning and temporal organization of supply chain of products to market.

\subsection{Costs of distribution networks.}

Distribution costs usually represent a significant component of the total cost of production of a commodity, varying accorder to their nature. In this way, the need to create a distribution network of products efficiently to ensure the competitiveness of production enterprises consumption is warranted.

In order to make the design and network planning and ensure a service level with minimum 
use of resources it is necessary to address the elements than depend distribution costs. These elements are transport vehicles, fixed facilities (warehouses, offices, terminals consolidation, multimodal terminals), and the transported goods themselves. Each of these terms has a set of associated costs that will justify the adoption of a network design strategies and specific shipment. At work, we will focus on studying the cost of transport vehicles.

The vehicles have two components associated cost depending on their physical and operational characteristics. On the one hand there will be a kilometric cost that will integrate the cost of fuel and vehicle maintenance. Second, the vehicle will have a fixed cost associated daily scale to represent the cost of insurance, taxes and depreciation of the vehicle, in case of own fleet, or rental service, subcontracting.

\subsection{Typology of delivery strategies.}

The demand for service in territory directly influences the strategies to follow to meet demand points and therefore the network topology of warehouses, consolidation centres and delegations of the logistics company. The optimal strategy to implement a distribution system must respond to a balance of different operating logistics costs.

The basic strategies which allow combination planning a physical distribution system are summarized as follows:

- Direct delivery (many to many): This strategy implies a distance to cover significant and a high number of vehicles for the distribution, so only considered when the costs of vehicle service are reduced when demand associated between all the origin-destination points can fill the capacity of the vehicle or when time constraints are important.

- Deliveries hub\&spoke: The construction of consolidation centres, hubs, includes the concentration of the merchandise at theses points and the optimization of vehicle capacity in scenarios with a non-uniform spatial distribution of demand. This strategy allows to increase the load factor of vehicles and accordingly the unit cost of transformation general level of the entire network and the total distribution time is reduced.

- Deliveries with multiples stops: The application of this strategy entail comparatively reduced routes composed of a high number of stops on each. Their application can be carried out when the cost and time to perform an extra stop on a route is reduced and costs scenarios with relatively high vehicle services.

\section{ELECTRIC VEHICLES AS A MEANS OF DELIVERY.}

At the present there are diverse companies that offer the Courier and parcel delivery in urban center in multiple cities (Seville, Córdoba, Granada, Valencia, Barcelona, Gijon, Bilbao, Santander, Mallorca, Malaga, etc.) through the use of bicycles and electric bicycles.

These enterprises normally offer a courier and parcel service in the urban center (internal 
mail and parcels for companies or organisms, mail or certified mail, special delivery, packaging, etc.).

As we have seen, the courier service by bicycles and electrics bicycles can offer in the center of big cities an attractive solution because each day to reduced access road traffic in their historic center, the high density of points of deals and population.

Below is we will study the use of electric vehicles, especially your bikes and motorcycles for the delivery of cities.

\subsection{Characteristics of electrical vehicles.}

Currently, a large number of brands of electric vehicles (cars, motorbikes, bicycles) that offer a wide variety in the electrical market. In this case in particular we will focus on bicycles and electrical motorcycles for its manageability and easy access the have in the certers of large cities.

\subsubsection{Electrik bikes.}

It is a bike which has been fitted an electric motor. This engine helps drivers to the advance of the bicycle, receiving power from a battery that recharges in the grid. Under current legislation, the motor can not exceed $25 \mathrm{~km} / \mathrm{h}$ and power should be less than $250 \mathrm{~W}$. It shoul also stop the engine when you stop pedaling.

These vehicles are characterized by being: fast, silent, ecological, healthy and efficient. No type or driving license or insurance to be necessary.

According to existing models in the market, the rate varies from $25 \mathrm{~km} / \mathrm{h}$ to $45 \mathrm{~km} / \mathrm{h}$, and even more. The autonomy varies considerably depending on the type of battery installed on the bike. Exist electric bikes able to of exceeding $200 \mathrm{~km}$, although the real range varies from $30 \mathrm{~km}$ to over $100 \mathrm{~km}$.

Exist high-speed electric bicycles, high speed e-bike, able to exceed $45 \mathrm{~km} / \mathrm{h}$ and whose engines have a power of more than $250 \mathrm{~W}$, being fitted with an accelerator. It is considered as mopeds.

The average consumption per $100 \mathrm{~km}$ is about $1 \mathrm{~kW} / \mathrm{h}$. According electricity tariffs in force the price can vary depending on the utility and the type of contract. It may take a price of $0,13 € / \mathrm{kW} / \mathrm{h}$.

The recharge can be perfomed in any socket of $220 \mathrm{~V}$. The maximum load is obtained between 3 and 8 hours, depending on battery model, capacity and the charger used. Almost all the batteries in electrical bicycles are removable, making charge them easier anywhere. 
A problem is the degradation of the batteries. Over time begins to show a reduction of autonomy that varies depending on the quality of the installed cells. The lifetime of the battery depends on many factors, so given an approximation if difficult. According to specialized companies can say that it is necessary to change to 5 years.

\subsubsection{Electric motorcycles.}

As do electric bicycles are powered by an engine that makes the bike to work, getting the energy of rechargeable batteries in the electrical network. They can get maximum speeds of over $45 \mathrm{~km} / \mathrm{h}$ and whose engines can get a power of several $\mathrm{CV}$.

Are characterized by not produce noise, be equally resistant than the gasoline motorcycles, ecological and require low maintenance.

In the present study we will focus on the scooters that are the most used in the area of distribution. This type of motorcycles usually have a speed between $45 \mathrm{~km} / \mathrm{h}$ and $85 \mathrm{~km} / \mathrm{h}$, depending on the model, whose engines can produce up to $5 \mathrm{CV}$. The autonomy varies according to the battery installed, some models can exceed $100 \mathrm{~km}$ of autonomy, although the actual autonomy varies from $30 \mathrm{~km}$ to just over $70 \mathrm{~km}$.

The average consumption per $100 \mathrm{~km}$ is about $1 \mathrm{kw} / \mathrm{h}$. As in electric bicycles. This being much less than that of conventional motorcycles.

Recharging and charging times is similar to electric bikes. Although in this case not usually removable batteries. They can be made at any socket $220 \mathrm{~V}$ and maximum load time also varies between 3 and 8 hours.

Like electric bicycles, present the problem of degradation of the batteries. Also encouraged to replace it every 5 years, although it may vary depending on usage model characteristics.

\subsection{Costs.}

When a company using electric vehicles for distribution in cities it is two costs. On one side the acquisition cost of the vehicles and the other the maintenance.

\subsubsection{Acquisition costs.}

The acquisition cost of electric vehicles is higher than traditional vehicles.

In the case of electric bicycles the average purchase price is 1000 euros. This mean is very good for express courier and small packages. In the case of large volumes, it is more advisable to use electric tricycles, the average cost of sales is 1500 euros. In addition to this amount must be added an extra cost due to adaptation of the vehicle to the needs of distribution. This extra cost can be estimated on average about 200 euros on bicycles and 
500 euros on tricycles.

In the case of electric motorcycles (scooters) the average purchase price is 3000 euros. As in bicycles and tricycles, it is necessary to adapt, assuming a cost of an additional 500 euros.

\subsubsection{Maintenance costs.}

Maintenance costs of both vehicles are low. In the case of electric bicycle maintenance cost it is almost equal to that of a conventional bicycle. The only problem the extra cost that produces batteries whether to chance due to their status.

In motorcycles, this cost is much lower. This is because the electric motor requires very little maintenance. While the gasoline engine needs its periodic reviews (oil change, filters, etc.) The other maintenance is the same for all motorcycles (brakes, housins, etc.). As in bicycles we have de drawback of batteries.

\section{CONCLUSIONS.}

The use of electric vehicles as a mean of distribution in the cities is increasingly more common. But there are insufficient data for a study of their behaviour. The ideas are drawn from this article are:

- Electric bikes can be a great help for the delivery of historic centers of cities, since every time the circulation of motor vehicles are restricted in them.

- Electric motorbikes are more suitable or distribution of the extensions of cities due to its characteristics.

- The acquisition of these vehicles is a great investment because of its cost.

- Maintenance costs and fuel are lower.

- They are environmentally friendly.

It is recommended that delivery companies use these means of transport in some pilot cities, chosen according to their characteristics (size, orography, etc.) to obtain reliable data and see if they can replace the media transport of fossil combustion.

\section{REFERENCES}

CNC (2011). Informe sobre el nuevo marco de regulación del sector postal tradicional en España. Comisión Nacional de la Competencia.

CORREOS (2013). Informe Anual 2012. Sociedad Estatal Correos y Telégrafos S.A. Madrid, 2013.

GOBIERNO DE ESPAÑA (2010). Informe Anual 2009. Los transportes, las infraestructuras y los servicios postales. Ministerio de Fomento. Centro de Publicaciones 
Secretaría General Técnica, 2010.

GOBIERNO DE ESPAÑA (2010b). Ley 43/2010, de 30 de diciembre, del servicio postal universal, de los derechos de los usuarios y del mercado postal. Boletín Oficial del Estado, 31 de diciembre de 2010, núm. 318, pp. 109195-109236.

UNIÓN EUROPEA (2008). Directiva 2008/6/CE del Parlamento y el Consejo, de 20 de febrero de 2008, por la que se modifica la Directiva 96/67/CE en relación con la plena realización del mercado interior de servicios postales comunitarios. Diario Oficial de la Unión Europea L52, 27 de febrero de 2008, pp. 3-20. 